\title{
Hypoxia disrupts the expression levels of circadian rhythm genes in hepatocellular carcinoma
}

\author{
CHAO YU $^{1 *}$, SHENG-LI YANG $^{2 *}$, XIEFAN FANG $^{3}$, JIAN-XIN JIANG $^{1}$, CHENG-YI SUN $^{1}$ and TAO HUANG ${ }^{4}$ \\ ${ }^{1}$ Department of Hepatobiliary Surgery, Affiliated Hospital of Guiyang Medical College, Guiyang, Guizhou 550001; \\ ${ }^{2}$ Department of General Surgery, Liyuan Hospital, Tongji Medical College, Huazhong University of Science and Technology, \\ Wuhan, Hubei 430077, P.R. China; ${ }^{3}$ Department of Pediatrics, College of Medicine, University of Florida, \\ Gainesville, FL 32610, USA; ${ }^{4}$ Department of Pediatrics, Tianyou Hospital, Wuhan University of \\ Science and Technology, Wuhan, Hubei 430064, P.R. China
}

Received February 10, 2014; Accepted December 19, 2014

DOI: $10.3892 / \mathrm{mmr} .2015 .3199$

\begin{abstract}
Disturbance in the expression of circadian rhythm genes is a common feature in certain types of cancer, however the mechanisms mediating this disturbance remain to be elucidated. The present study aimed to investigate the effect of hypoxia on the expression of circadian rhythm genes in liver cancer cells and to identify the mechanisms underlying this effect in hepatocellular carcinoma (HCC). The HCC cell line, PLC/PRF/5. was treated with either a vehicle control or $\mathrm{CoCl}_{2}$ at 50,100 or $200 \mu \mathrm{M}$ for $24 \mathrm{~h}$. Following treatment, the protein expression levels of hypoxia-inducible factor (HIF)- $1 \alpha$ and HIF-2 $\alpha$ were detected by western blotting and the mRNA expression levels of circadian rhythm genes, including circadian locomotor output cycles kaput (Clock), brain and muscle Arnt-like 1 (Bmall), period (Per) 1, Per2, Per3, cryptochrome (Cry) 1, Cry 2 and casein kinase I $\varepsilon(C K I \varepsilon)$, were detected by reverse transcription quantitative polymerase chain reaction (RT-qPCR). Expression plasmids containing HIF-1 $\alpha$ or HIF- $2 \alpha$ were transfected into the PLC/PRF/5 cells using liposomes and RT-qPCR was used to determine the effects of the transfections on the expression levels of circadian rhythm genes. Following treatment with $\mathrm{CoCl}_{2}$, the protein expression levels of HIF-1 $\alpha$ and $\mathrm{HIF}-2 \alpha$ were upregulated in a $\mathrm{CoCl}_{2}$ concentration-dependent manner. The mRNA expression levels of Clock, Bmall and Cry 2 were increased, and the mRNA expression levels of Perl, Per2, Per3, Cryl and CKIE were decreased following $\mathrm{CoCl}_{2}$
\end{abstract}

Correspondence to: Professor Jian-Xin Jiang or Professor Cheng-Yi Sun, Department of Hepatobiliary Surgery, Affiliated Hospital of Guiyang Medical College, 28 Guiyi Street, Guiyang, Guizhou 550001, P.R. China

E-mail: jjx731003@163.com

E-mail: chengyisun2014@163.com

*Contributed equally

Key words: hypoxia, hypoxia-inducible factor- $1 \alpha$, hypoxia-inducible factor- $2 \alpha$, hepatocellular carcinoma, circadian clock treatment $(\mathrm{P}<0.05)$. In the $\mathrm{PLC} / \mathrm{PRF} / 5$ cells transfected with the plasmid containing HIF-1 $\alpha$, the mRNA expression levels of Clock, Bmal1 and Cry 2 were increased, and the mRNA expression levels of Perl, Per2, Per3, Cryl and CKIE were decreased. In the PLC/PRF/5 cells transfected with the plasmid containing HIF-2 $\alpha$, the mRNA expression levels of Clock, Bmall, Perl, Cry1, Cry2 and CKIE were upregulated, and the mRNA expression levels of Per 2 and Per3 were downregulated $(\mathrm{P}<0.05)$. A hypoxic microenvironment may contribute to the disturbance in the expression of circadian genes in HCC. HIF-1 $\alpha$ and HIF- $2 \alpha$ are involved in this process and have redundant, but not identical effects.

\section{Introduction}

The circadian clock is an inner rhythm, which regulates daily rhythmic fluctuations in several physiological processes in organisms $(1,2)$. In humans, the circadian clock is regulated by a transcription-translation feedback loop, which consists of multiple biological clock genes, including circadian locomotor output cycles kaput (Clock), brain and muscle Arnt-like-1 (Bmal1), period (Per) 1, Per2, Per3, cryptochrome (Cry)1, Cry 2 and casein kinase $I \varepsilon(C K I \varepsilon)$ (3). Clock and Bmall form heterodimers and bind to E-boxes, which are a CACGTG nucleotide sequence in the promoter, driving the rhythmic transcription of the Per and Cry genes. The Per and Cry proteins are translated in the cytoplasm and form Per-Cry complexes, which translocate into the nucleus to suppress the further transcription of $\mathrm{Per}$ and Cry, which is mediated by Bmall and Clock (4). Another transcriptional loop is to modulate the protein stability of Per and Bmall by CKIE-induced phosphorylation (5).

The potential association between the disruption of circadian rhythm and tumor development has prompted widespread concern $(6,7)$. An increasing number of studies have demonstrated that disruption of the circadian rhythm is associated with the development and progression of several types of tumor, including colorectal cancer (8), breast cancer (9) and pancreatic cancer (10). Altered expression of the circadian genes has also been observed in hepatocellular carcinoma (HCC) (11), however, the predominant factors that disturb the circadian clock in HCC remain to be elucidated. Liver cancer and other 
types of solid tumor are generally in a hypoxic state (12-14), and an association between hypoxia and the disturbance of the circadian clock has been reported (15). The present study aimed to investigate the causal association between hypoxia and the abnormal expression of circadian genes in HCC cells.

\section{Materials and methods}

Cell culture and transfection. The normal human HCC cell line, PLC/PRF/5, was purchased from the Institute of Biochemistry and Cell Biology (SIBS) of the Chinese Academy of Sciences (Shanghai, China). Expression plasmids containing hypoxia-inducible factor (HIF)- $1 \alpha$ and HIF-2 $\alpha$, and a control plasmid, pcDNA3.1, were purchased from Shanghai GeneChem Co., Ltd. (Shanghai, China). The cells were grown in Dulbecco's modified Eagle's medium (DMEM; HyClone, Logan, UT, USA) containing $10 \%$ fetal bovine serum (FBS; Invitrogen Life Technologies, Carlsbad, CA, USA), $2 \mathrm{mmol} / \mathrm{l} \mathrm{L-glutamine} \mathrm{(HyClone),}$ $50 \mathrm{U} / \mathrm{ml}$ penicillin and $50 \mathrm{~g} / \mathrm{ml}$ streptomycin (HyClone) at $37^{\circ} \mathrm{C}$ in an atmosphere of $5 \% \mathrm{CO}_{2}$ in air. PLC/PRF/5 cells at between 70 and $80 \%$ confluence were then transfected with the different plasmids using Lipofectamine 2000 (Invitrogen Life Technologies) according to the manufacturer's instructions. In brief, $4 \mu \mathrm{g}$ plasmid pcDNA3.1, pcDNA3.1-HIF-1 $\alpha$ and pcDNA3.1-HIF-2 $\alpha$ were diluted in $250 \mu$ Opti-MEM medium (Invitrogen Life Technologies) without serum, and mixed. In addition, $10 \mu 1$ Lipofectamine 2000 was diluted in $250 \mu \mathrm{l}$ serum-free Opti-MEM medium, mixed gently and incubated for $5 \mathrm{~min}$ at room temperature. Following incubation, the diluted plasmids were combined with the diluted Lipofectamine 2000 (total volume, $500 \mu \mathrm{l}$ ), mixed gently and incubated for $20 \mathrm{~min}$ at room temperature. Subsequently, $500 \mu \mathrm{l}$ dilution mixture was added to each well of a 6 -well plate. The transfected cells were incubated at $37^{\circ} \mathrm{C}$ for $6 \mathrm{~h}$ prior to the medium being replaced with fresh DMEM containing $10 \% \mathrm{FBS}$ and the cells were cultured for a further $18 \mathrm{~h}$ at $37^{\circ} \mathrm{C}$ with $5 \% \mathrm{CO}_{2}$. The protein and mRNA expression levels of the target genes in the transfected cells were analyzed by either reverse transcription quantitative polymerase chain reaction (RT-qPCR) or westernblotting.

Protein preparation and western blot analysis. The $\mathrm{PLC} / \mathrm{PRF} / 5$ cells were treated with either a vehicle (phosphate-buffered saline; Boster Biological Technology, Ltd, Wuhan, China) or $\mathrm{CoCl}_{2}$ at 50,100 , or $200 \mu \mathrm{M}$ for $24 \mathrm{~h}$ in a 6 -well plate at a cell density of $7 \times 10^{5}$ cells/well at $37^{\circ} \mathrm{C}$ with $5 \% \mathrm{CO}_{2}$. Cells were cultured with DMEM containing $10 \%$ FBS. The cells were collected and homogenized in lysis buffer (Boster Biological Technology, Ltd) containing $50 \mathrm{mmol} / 1$ Tris- $\mathrm{HCl}$ (pH 8.5), $150 \mathrm{~mol} / 1 \mathrm{NaCl}, 0.2 \mathrm{~g} / \mathrm{l} \mathrm{NaN}_{3}$, $0.1 \mathrm{~g} / 1$ sodium dodecyl sulphate (SDS), $100 \mu \mathrm{g} / \mathrm{ml}$ phenylmethylsulfonyl fluoride, $1 \mu \mathrm{g} / \mathrm{ml}$ aprotinin, $10 \mathrm{ml} / 1 \mathrm{NP}-40$ and $5 \mathrm{~g} / \mathrm{l}$ sodium deoxycholate. The cells were then centrifuged at $14,000 \mathrm{x}$ g for $15 \mathrm{~min}$ to remove the cellular debris and the protein concentrations were determined using the Bradford method (16). Protein expression was quantified using a Pierce BCA Protein Assay kit (Thermo Fisher Scientific Inc., Rockford, IL, USA) according to the manufacturer's instructions. Western blotting was performed, as described previously (17). The proteins (30-50 $\mu \mathrm{g}$ ) were separated by SDS-polyacrylamide gel electrophoresis using 10\% SDS polyacrylamide gels (Boster Biological Technology, Ltd), they were then transferred onto polyvinylidene fluoride membranes (Invitrogen Life Technologies) and subsequently blocked in 5\% nonfat milk (Boster Biological Technology,Ltd) in Tris-buffered saline containing 0.1\% Tween-20 (Boster Biological Technology, Ltd) for $2 \mathrm{~h}$. The membranes were then incubated with primary mouse anti-human monoclonal

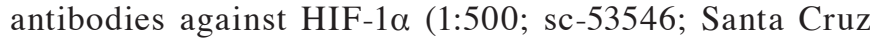
Biotechnology, Inc., Santa Cruz, CA, USA) and HIF-2 $\alpha$ (1:500, sc-13596; Santa Cruz Biotechnology, Inc.) or primary mouse anti-gizzard monoclonal antibodies against $\beta$-actin $(1: 2,000$; sc-47778; Santa Cruz Biotechnology, Inc.) for $1 \mathrm{~h}$ at $37^{\circ} \mathrm{C}$ and, followed by incubation overnight at $4^{\circ} \mathrm{C}$. The membranes were subsequently incubated with the appropriate horseradish peroxidase-conjugated monoclonalgoatanti-mousesecondary immunoglobulin $\mathrm{G}$ antibodies for $1 \mathrm{~h}$ at room temperature and the bands were then visualized using an enhanced chemiluminescence detection system (SuperSignal West Pico substrate, cat. no. 34080; Thermo Fisher Scientific Inc.).

RNA extraction and RT first-strand cDNA synthesis. The transiently transfected cells (6-well plate at a cell density of $1 \times 10^{6}$ cells/well) were used to isolate the total RNA using TRIzol reagent (Invitrogen Life Technologies). The concentration and quality of the RNA were determined using a Nano Drop Spectrophotometer (Nano Drop Technologies, Inc., Wilmington, DE, USA) to measure absorbance at 200-350 nm. cDNA synthesis was performed at $42^{\circ} \mathrm{C}$ for $60 \mathrm{~min}$ in a reaction mixture $(25 \mu \mathrm{l}$; Promega Corp., Madison, WI, USA) containing $2 \mu \mathrm{g}$ RNA, $1.6 \mu \mathrm{M}$ Oligo (dT)18, $0.6 \mu \mathrm{M} d \mathrm{NTP}, 200 \mathrm{U} / \mu \mathrm{l} \mathrm{M}-\mathrm{MLV}$ reverse transcriptase and the reaction buffer supplied.

qPCR. Following RT, the cDNA samples were diluted 1:5 with RNase-free water. The primers were designed, according to the cDNA sequences in the GeneBank database (http://www. ncbi.nlm.nih.gov/genbank/) using Primers Express 3.0 software (PE Applied Biosystems, Foster City,. CA, USA) (18) and are listed in Table I. Each reaction contained $10 \mu \mathrm{l}$ 2X SYBR Green mix (Invitrogen Life Technologies), $2 \mu 1$ cDNA template, $0.6 \mu \mathrm{l}$ forward primer $(10 \mu \mathrm{M}), 0.6 \mu \mathrm{l}$ reverse primer $(10 \mu \mathrm{M})$ and double distilled $\mathrm{H}_{2} \mathrm{O}$ in a total volume of $20 \mu \mathrm{l}$. qPCR was performed on a Real-Time PCR system 7500 (Applied Biosystems, Foster City, CA, USA) with the following cycling program: One cycle at $94^{\circ} \mathrm{C}$ for $1 \mathrm{~min}$ for denaturation and 40 cycles at $94^{\circ} \mathrm{C}$ for $60 \mathrm{sec}, 55^{\circ} \mathrm{C}$ for $60 \mathrm{sec}$ and $72^{\circ} \mathrm{C}$ for $60 \mathrm{sec}$ (19). The average fluorescence was automatically recorded and the baseline and threshold were adjusted using the ABI 7500 software system (excitation, $497 \mathrm{~nm}$; and emision, $520 \mathrm{~nm}$ ). The cycle threshold $(\mathrm{Ct})$ values were determined and the data were analyzed using the $2^{-\triangle \Delta C T}$ method and were normalized against the expression of $\beta$-actin in each sample (20).

Statistical analysis. The data were analyzed using SPSS version 13.0 software (SPSS, Inc., Chicago, IL, USA). Student's t-test was used to compare the differences between two groups and one-way analysis of variance was used to 
Table I. Polymerase chain reaction primers and conditions.

\begin{tabular}{|c|c|c|c|}
\hline Gene & Primer $\left(5^{\prime}-3^{\prime}\right)$ & Temperature $\left({ }^{\circ} \mathrm{C}\right)$ & Product size (bp) \\
\hline \multicolumn{4}{|l|}{ Perl } \\
\hline Forward & CCATTGTCCGCATCCTTCC & \multirow{2}{*}{60.4} & \multirow{2}{*}{142} \\
\hline Reverse & TGTTCCCTCCCAACCTTCG & & \\
\hline \multicolumn{4}{|l|}{ Per2 } \\
\hline Forward & CTATTCTCCCATTCGGTTTCG & \multirow{2}{*}{60.0} & \multirow{2}{*}{128} \\
\hline Reverse & CCACCCTGACTTTGTGCCTC & & \\
\hline \multicolumn{4}{|l|}{ Per3 } \\
\hline Forward & GTGGAGGTGAAGACAGAAAGCA & \multirow{2}{*}{59.7} & \multirow[t]{2}{*}{117} \\
\hline Reverse & TGAGACAGCAAGGTTCCGATT & & \\
\hline \multicolumn{4}{|l|}{ Cryl } \\
\hline Forward & СААССТССАТТСАТСТТТСС & \multirow{2}{*}{58.9} & \multirow{2}{*}{151} \\
\hline Reverse & CTCATAGCCGACACCTTC & & \\
\hline \multicolumn{4}{|l|}{ Cry2 } \\
\hline Forward & AACCACGACGAGACCTACGG & \multirow{2}{*}{61.0} & \multirow{2}{*}{178} \\
\hline Reverse & GGGAGTTGGCGTTCATTCG & & \\
\hline \multicolumn{4}{|l|}{ Clock } \\
\hline Forward & GCAGCAGCAGCAGCAGAG & \multirow{2}{*}{61.9} & \multirow{2}{*}{149} \\
\hline Reverse & CAGCAGAGAGAATGAGTTGAGTTG & & \\
\hline \multicolumn{4}{|l|}{ Bmall } \\
\hline Forward & TGCCACCAATCCATACACAGAAG & \multirow{2}{*}{60.9} & \multirow{2}{*}{123} \\
\hline Reverse & TTCCCTCGGTCACATCCTACG & & \\
\hline \multicolumn{4}{|l|}{$C K I \underline{\varepsilon}$} \\
\hline Forward & TCAGCGAGAAGAAGATGTC & \multirow{2}{*}{58.9} & \multirow{2}{*}{149} \\
\hline Reverse & GAAGAGGTTGCGGAAGAG & & \\
\hline \multicolumn{4}{|l|}{$\underline{\beta}$-actin } \\
\hline Forward & AGTTGCGTTACACCCTTTCTTGAC & \multirow{2}{*}{63.9} & \multirow{2}{*}{171} \\
\hline Reverse & GCTCGCTCCAACCGACTGC & & \\
\hline \multicolumn{4}{|l|}{$H I F-1 \underline{\alpha}$} \\
\hline Forward & САТСТССАТСТССТАСССАСА & \multirow{2}{*}{58.3} & \multirow{2}{*}{105} \\
\hline Reverse & СTTTTCCTGCTCTGTTTGGTG & & \\
\hline$H I F-2 \underline{\alpha}$ & & & \\
\hline Forward & TCATGCGACTGGCAATCAGC & 61.3 & 141 \\
\hline Reverse & GTCACCACGGCAATGAAACC & & \\
\hline
\end{tabular}

Per, period; Cry, cryptochrome; Clock, circadian locomotor output cycles kaput; Bmal, brain and muscle Arnt-like 1; CKIE, casein kinase Iع; HIF, hypoxia-inducible factor.

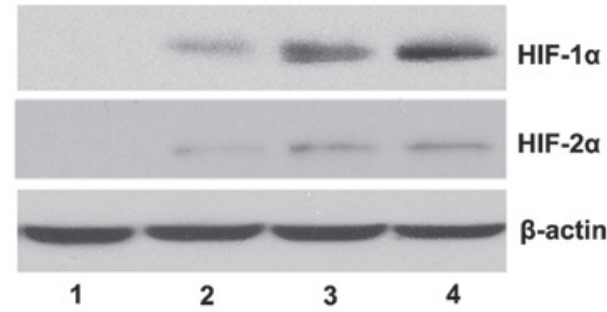

Figure 1. Detection of the protein expression levels of HIF-1 $\alpha$ and HIF-2 $\alpha$ in the PLC/PRF/5 cells exposed to various concentrations of $\mathrm{CoCl}_{2}$ by western blotting. Lanes 1-4 indicate the protein expression levels in cells treated with vehicle (phosphate-buffered saline) or $\mathrm{CoCl}_{2}$ at 50,100 , or $200 \mu \mathrm{M}$, respectively. The protein expression levels of HIF-1 $\alpha$ and HIF- $2 \alpha$ were increased by $\mathrm{CoCl}_{2}$ in a dose-dependent manner. HIF, hypoxia-inducible factor. compare the differences among multiple groups. The data are expressed as the mean \pm standard deviation and $\mathrm{P}<0.05$ was considered to indicate a statistically significant difference.

\section{Results}

A hypoxic environment disrupts the expression levels of circadian genes in HCC cells. The western blotting results revealed that, in the absence of $\mathrm{CoCl}_{2}$, the protein expression levels of HIF-1 $\alpha$ and HIF- $2 \alpha$ were not detectable, however, their expression levels were significantly upregulated in the presence of $\mathrm{CoCl}_{2}$ in a dose-dependent manner (Fig. 1). The qPCR results demonstrated that treatment with 

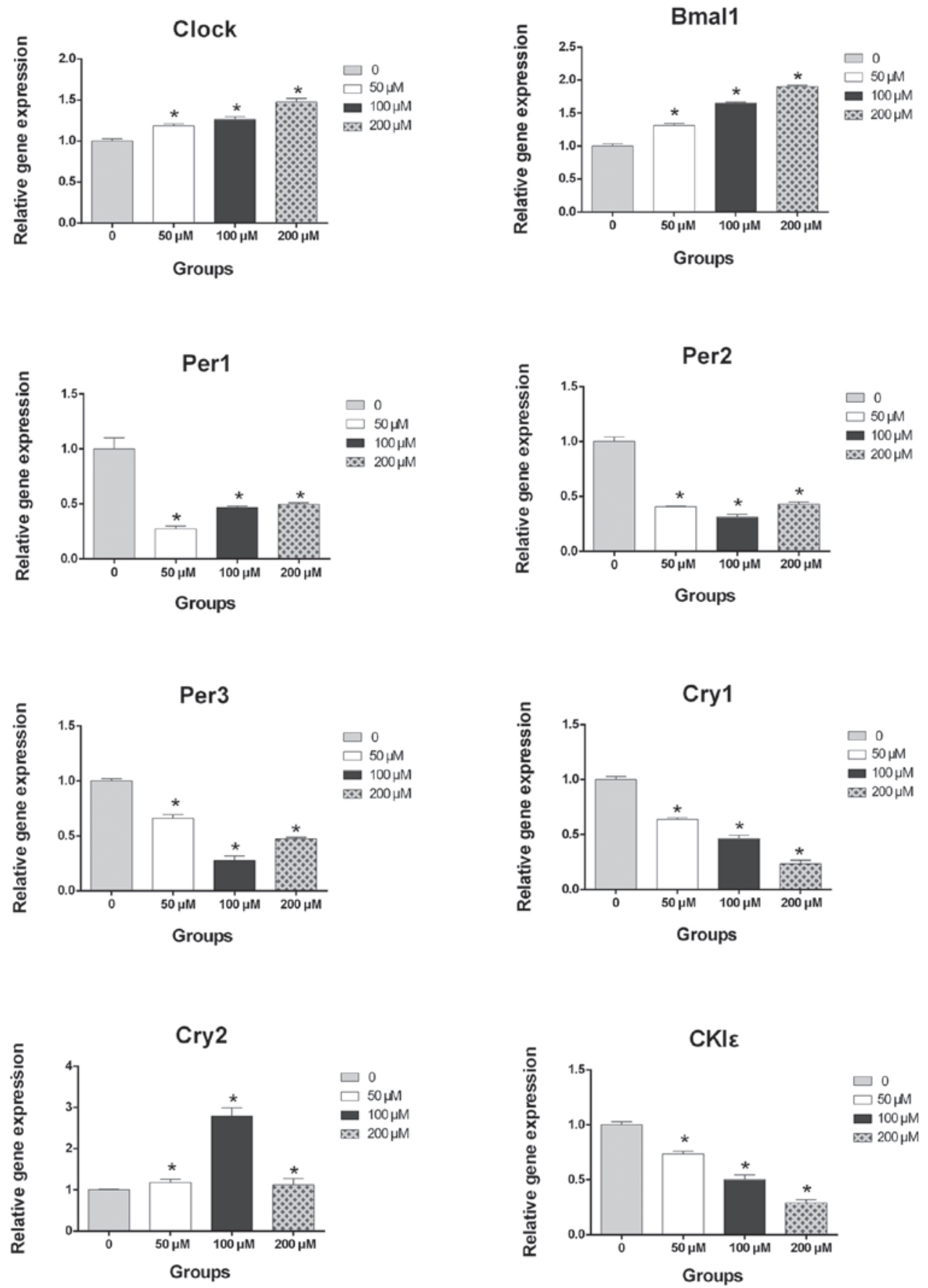

Figure 2. Reverse transcription quantitative polymerase chain reaction detection of the mRNA expression levels of Clock, Bmal1, Perl, Per 2, Per 3, Cryl, Cry 2 and $C K I \varepsilon$ in the PLC/PRF/5 cells exposed to a vehicle (phosphate-buffered saline) or various concentrations of $\mathrm{CoCl}_{2}$. $\mathrm{mRNA}$ expression levels of $C l o c k$, Bmall and Cry2 were increased and the expression levels of Per1, Per2, Per3, Cry1 and CKIE were reduced, in a CoCl ${ }_{2}$ concentration-dependent manner. Values are presented as the mean \pm standard deviation (" $\mathrm{P}<0.05$, vs. vehicle control). Clock, circadian locomotor output cycles kaput; Bmal, brain and muscle Arnt-like-1; Per, period; Cry, cryptochrome; CKIE, casein kinase I $\varepsilon$.

$\mathrm{CoCl}_{2}$ increased the mRNA expression levels of Clock, Bmall and Cry2 and decreased the mRNA expression levels of Per1, Per2, Per3, Cryl and CKIE (Fig. 2). Notably, the mRNA expression levels of Clock, Bmall, Cryl and CKIE were dysregulated by treatment with $\mathrm{CoCl}_{2}$ in a concentration-dependent manner ( $\mathrm{P}<0.05$; Fig. 2).

HIF-1 $\alpha$ and HIF-2 $\alpha$ disrupt the expression levels of circadian genes in HCC cells. HIF-1 $\alpha$ and HIF-2 $\alpha$ are the predominant transcription factors in a hypoxic microenvironment. In order to examine the effects of HIF-1 $\alpha$ and HIF-2 $\alpha$ on the expression levels of circadian genes, PLC/PRF/5 cells were transfected with HIF-1 $\alpha$ or HIF- $2 \alpha$ expression plasmids. The mRNA and protein expression levels of HIF-1 $\alpha$ and HIF-2 $\alpha$ in the transfected cells were confirmed by RT-qPCR (Fig. 3A) and western blotting (Fig. 3B). Subsequently, the expression levels of the circadian genes were determined in the transfected cells. The mRNA expression levels of Clock, Bmall and Cry2 were increased and the expression levels of Perl, Per2, Per3,Cryl and CKIE were decreased in the PLC/PRF/ 5 cells transfected with the HIF-1 $\alpha$ 
A

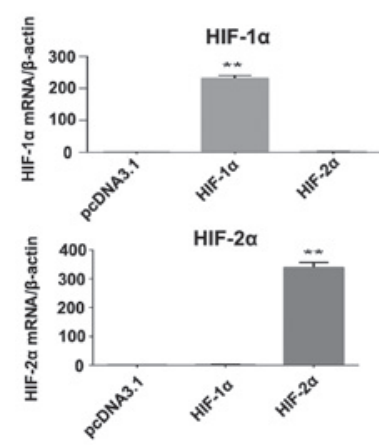

B

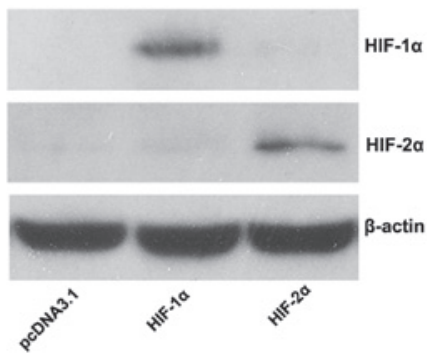

Figure 3. Expression levels of HIF-1 $\alpha$ and HIF-2 $\alpha$ are upregulated in the PLC/PRF/5 cells transfected with either the HIF-1 $\alpha$ or HIF-2 $\alpha$ expression vector compared with the control transfection using pcDNA3.1. (A) mRNA expression levels of HIF-1 $\alpha$ and HIF-2 $\alpha$ were detected by reverse transcription quantitative polymerase chain reaction following transfection with different plasmids. The mRNA expression levels were normalized against $\beta$-actin and the data are presented as the relative mRNA expression compared with the control. Values are presented as the mean \pm standard deviation. The results are an average of three independent experiments ( ${ }^{* *} \mathrm{P}<0.01$, vs. control). (B) Western blot analysis demonstrating the protein expression levels of HIF-1 $\alpha$ and HIF- $2 \alpha$ in the PLC/PRF/5 cells transfected with either the pcDNA3.1, HIF-1 $\alpha$ or HIF-2 $\alpha$ vector. $\beta$-actin was used as a loading control. HIF, hypoxia-inducible factor; PC, plasmid control.
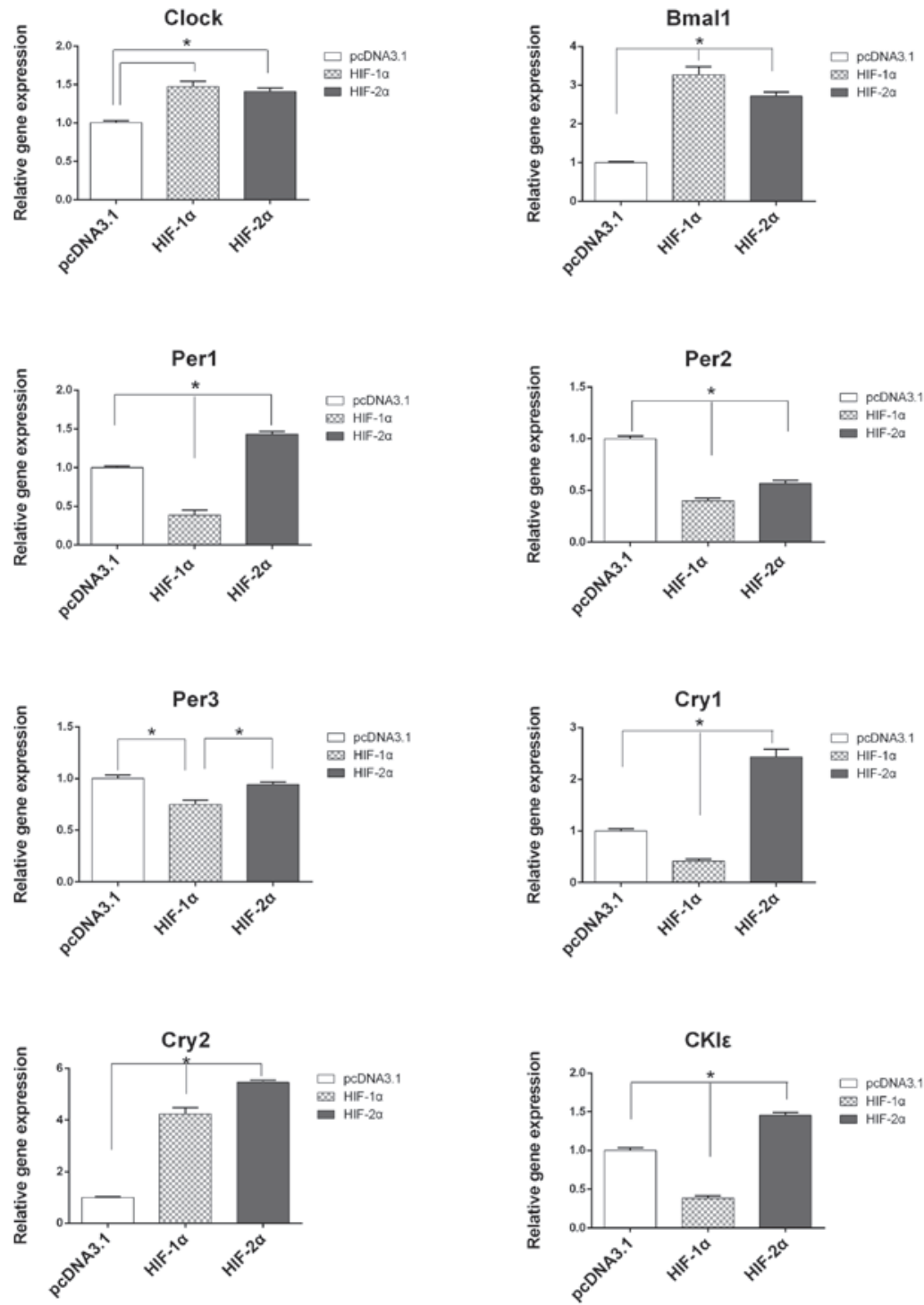

Figure 4. Comparisons of the mRNA expression levels of circadian genes in HCC cells following transfection with either the pcDNA3.1 (control), HIF-1 $\alpha$ or HIF-2 $\alpha$ plasmids. The mRNA expression levels of Clock, Bmal1 and Cry2 were increased and the expression levels of Perl, Per2, Per3, Cryl and CKIE were decreased in the PLC/PRF/5 cells following transfection with the HIF-1 $\alpha$ plasmid, compared with the control. Following transfection with the HIF-2 $\alpha$ plasmid, the mRNA expression levels of Clock, Bmall, Perl, Cryl, Cry2 and CKIE were upregulated and the mRNA expression levels of Per2, Per3 were downregulated. The mRNA expression levels were normalized against $\beta$-actin and are presented as the relative mRNA expression levels compared with the control. Values are presented as the mean \pm standard deviation. The results are an average of three independent experiments (" $\mathrm{P}<0.05$, vs. control). Clock, circadian locomotor output

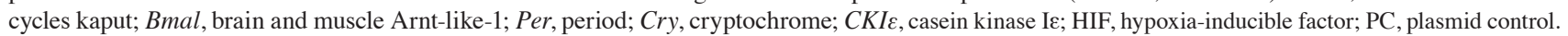


plasmid compared with the control cells (Fig. 4). Transfection with the HIF-2 $\alpha$ plasmid increased the mRNA expression levels of Clock, Bmall, Perl, Cryl, Cry2 and CKIE, and decreased the expression levels of Per 2 and Per3 (P<0.05; Fig. 4).

\section{Discussion}

Investigations into the association between circadian rhythm and cancer originated from several large epidemiological studies, which revealed that night-shift workers have higher incidences of breast, colon and prostate cancer $(8,21,22)$. Further studies have demonstrated that disturbances in the expression of circadian genes is common in several types of cancer $(7,10,23-28)$. The expression levels of between 5 and $15 \%$ of genes, including key cell cycle regulators, tumor suppressor genes and oncogenes, are regulated by circadian rhythm and are driven by clock genes $(29,30)$. Therefore, circadian genes regulate the timing of DNA repair, apoptosis and cell proliferation $(29,30)$. Disruption of the circadian rhythm may affect cellular proliferation and promote tumor formation. It has been demonstrated that disruptions to the circadian clock accelerate carcinogenesis in murine cell models $(31,32)$.

Although disturbances in the expression of circadian rhythm genes have been found to be closely associated with the occurrence and development of HCC and other types of tumor $(33,34)$, the mechanisms underlying how circadian rhythm affects tumor growth remain to be elucidated. It was reported that there is a bidirectional interaction between the hypoxic signaling pathway and the circadian clock (15). Although $\mathrm{HCC}$ is one of the most hypervascularized types of tumor, with rich blood perfusion, it contains hypoxic regions due to rapid cell proliferation and the formation of aberrant blood vessels, particularly in patients with liver cirrhosis (12). The present study demonstrated, in a $\mathrm{CoCl}_{2}$-induced hypoxic environment that the mRNA expression levels of all the circadian clock genes were altered, with upregulation of Clock, Bmall and Cry2, and downregulation of Per1, Per2, Per3, Cryl and CKIE. Lin et al (11) demonstrated that the expression levels of Perl, Per2, Per3 and Cry2 in HCC cancerous tissues were significantly reduced compared with their expression levels in paired peritumoral tissues, whereas no significant differences were observed in the expression levels of Clock, Bmall, Cryl and CK1ع. Comparing the two studies revealed that the expression pattern of circadian genes in HCC cells in a hypoxic environment was similar to their expression pattern in HCC tissues. Therefore, hypoxia is one of the causes of abnormal expression of the clock genes in HCC.

Two hypoxia-specific transcription factors, HIF-1 $\alpha$ and HIF- $2 \alpha$, are important in the response to hypoxia. These proteins form heterodimers, which consist of a constitutively expressed HIF-1 $\beta$ subunit and an $\mathrm{O}_{2}$-regulated HIF-1 $\alpha$ or HIF-2 $\alpha$ subunit. HIF-1 $\alpha$ and HIF- $2 \alpha$ function as transcription factors only under hypoxic conditions and, in well-oxygenated cells, hydroxylation of the proline residues by prolyl hydroxylase domain protein 2 promotes the interaction of HIF-1 $\alpha$ and HIF-2 $\alpha$ with the von-Hippel-Lindau tumor suppressor protein, which recruits E3 ubiquitin-protein ligase, targetingHIF-1 $\alpha$ and HIF-2 $\alpha$ for degradation by the ubiquitin-proteasome system (35). Although HIF-1 $\alpha$ and HIF-2 $\alpha$ have similar structures and common hypoxia-response elements, their target genes are not identical (36). In addition, the transcriptional activities of HIF- $1 \alpha$ and HIF-2 $\alpha$ are different, even when targeting an identical set of genes $(36,37)$. The present study revealed that HIF- $1 \alpha$ and HIF- $2 \alpha$ altered the mRNA expression of the circadian clock genes in HCC cells. HIF-1 $\alpha$ upregulated the expression levels of Clock, Bmall and Cry2, and downregulated the expression levels of Perl, Per2, Per3, Cryl and CKIE. HIF-2 $\alpha$ increased the expression levels of Clock, Bmall, Perl, Cryl, Cry 2 and CKIE, and decreased the expression levels of Per2 and Per3. Therefore, it was observed that HIF-1 $\alpha$ and HIF- $2 \alpha$ have the opposite regulatory effects on the mRNA expression levels of Perl, Cryl and CKIE. Among these circadian genes, Perl is involved in the DNA damage response pathways, as a cofactor of checkpoint kinase 2 for the activation of ataxia telangiectasia mutated and is considered to be a potential tumor suppressor gene $(23,34,38)$. The results of the present study suggested that HIF-1 $\alpha$ and HIF- $2 \alpha$ were involved in modulating the circadian clock by exhibiting similar, but not identical, effects and further supports our previous findings that HIF- $1 \alpha$ and HIF- $2 \alpha$ may have different effects in the occurrence and development of HCC (39).

In conclusion, the expression levels of circadian genes were disrupted in the hypoxic environment and the overexpression of HIF- $1 \alpha$ and HIF- $2 \alpha$ altered the expression pattern of circadian genes. Further investigations are required to confirm the effect of hypoxia on the circadian clock and the association between hypoxia, circadian rhythm and HCC carcinogenesis. The present study suggested that abnormal circadian rhythm has a detrimental role in the occurrence and development of liver cancer. Therefore, maintaining a normal circadian rhythm may be a novel therapeutic strategy for the treatment of liver cancer.

\section{Acknowledgements}

This study was supported by a grant from The National Natural Science Foundation of China (no. 81160311).

\section{References}

1. Barclay JL, Tsang AH and Oster H: Interaction of central and peripheral Clocks in physiological regulation. Prog Brain Res 199: 163-181, 2012.

2. Eckel-Mahan K and Sassone-Corsi P: Metabolism and the circadian Clock converge. Physiol Rev 93: 107-135, 2013.

3. Mazzoccoli G, Pazienza V and Vinciguerra M: Clock genes and Clock-controlled genes in the regulation of metabolic rhythms. Chronobiol Int 29: 227-251, 2012.

4. Isojima Y, Okumura N and Nagai K: Molecular mechanism of mammalian circadian Clock. J Biochem 134: 777-784, 2003.

5. Eide EJ and Virshup DM: Casein kinase I: another cog in the circadian Clockworks. Chronobiol Int 18: 389-398, 2001.

6. Greene MW: Circadian rhythms and tumor growth. Cancer Lett 318: 115-123, 2012.

7. Savvidis C and Koutsilieris M: Circadian rhythm disruption in cancer biology. Mol Med 18: 1249-1260, 2012.

8. Brudnowska J and Peplonska B: Night shift work and cancer risk: a literature review. Med Pr 62: 323-338, 2011 (In Polish).

9. Leonardi GC, Rapisarda V, Marconi A, et al: Correlation of the risk of breast cancer and disruption of the circadian rhythm (Review). Oncol Rep 28: 418-428, 2012.

10. Relles D, Sendecki J, Chipitsyna G, Hyslop T, Yeo CJ and Arafat HA: Circadian gene expression and clinicopathologic correlates in pancreatic cancer. J Gastrointest Surg 17: 443-450, 2013.

11. Lin YM, Chang JH, Yeh KT, et al: Disturbance of circadian gene expression in hepatocellular carcinoma. Mol Carcinog 47: 925-933, 2008 
12. Aravalli RN, Cressman EN and Steer CJ: Cellular and molecular mechanisms of hepatocellular carcinoma: an update. Arch Toxicol 87: 227-247, 2013.

13. Yang Y, Sun M, Wang L and Jiao B: HIFs, angiogenesis, and cancer. J Cell Biochem 114: 967-974, 2013

14. Tang CM and Yu J: Hypoxia-inducible factor-1 as a therapeutic target in cancer. J Gastroenterol Hepatol 28: 401-405, 2013.

15. Egg M, Köblitz L, Hirayama J, et al: Linking oxygen to time: the bidirectional interaction between the hypoxic signaling pathway and the circadian Clock. Chronobiol Int 30: 510-529, 2013.

16. Bradford MM: A rapid and sensitive method for the quantitation of microgram quantities of protein utilizing the principle of protein-dye binding. Analytical biochemistry 72: 248-254, 1976.

17. He YW, Wang HS, Zeng J, et al: Sodium butyrate inhibits interferon-gamma induced indoleamine 2,3-dioxygenase expression via STAT1 in nasopharyngeal carcinoma cells. Life Sci 93: 509-515, 2013

18. Fang X, Dong W, Thornton C, Scheffler B and Willett KL: Benzo(a)pyrene induced glycine $\mathrm{N}$-methyltransferase messenger RNA expression in Fundulus heteroclitus embryos. Mar Environ Res 69 Suppl: S74-S76, 2010.

19. Fang X, Thornton C, Scheffler BE and Willett KL: Benzo[a] pyrene decreases global and gene specific DNA methylation during zebrafish development. Environ Toxicol Pharmacol 36: 40-50, 2013

20. Buscariollo DL, Fang X, Greenwood V, Xue H, Rivkees SA and Wendler CC: Embryonic caffeine exposure acts via A1 adenosine receptors to alter adult cardiac function and DNA methylation in mice. PLoS One 9: e87547, 2014.

21. Menegaux F, Truong T, Anger A, et al: Night work and breast cancer: a population-based case-control study in France (the CECILE study). Int J Cancer 132: 924-931, 2013.

22. Lahti T, Merikanto I and Partonen T: Circadian Clock disruptions and the risk of cancer. Ann Med 44: 847-853, 2012.

23. Chen R, Yang K, Zhao NB, et al: Abnormal expression of PER1 circadian-Clock gene in oral squamous cell carcinoma. Onco Targets Ther 5: 403-407, 2012.

24. Mazzoccoli G, Panza A, Valvano MR, et al: Clock gene expression levels and relationship with clinical and pathological features in colorectal cancer patients. Chronobiol Int 28: 841-851, 2011.

25. Krugluger W, Brandstaetter A, Kállay E, et al: Regulation of genes of the circadian Clock in human colon cancer: reduced period-1 and dihydropyrimidine dehydrogenase transcription correlates in high-grade tumors. Cancer Res 67: 7917-7922, 2007.
26. Wang X, Yan D, Teng M, et al: Reduced expression of PER3 is associated with incidence and development of colon cancer. Ann Surg Oncol 19: 3081-3088, 2012.

27. Oshima T, Takenoshita S, Akaike M, et al: Expression of circadian genes correlates with liver metastasis and outcomes in colorectal cancer. Oncol Rep 25: 1439-1446, 2011.

28. Wang Y, Hua L, Lu C and Chen Z: Expression of circadian Clock gene human Period2 (hPer2) in human colorectal carcinoma. World J Surg Oncol 9: 166, 2011.

29. Canaple L, Kakizawa T and Laudet V: The days and nights of cancer cells. Cancer Res 63: 7545-7552, 2003.

30. Schibler U: The daily timing of gene expression and physiology in mammals. Dialogues Clin Neurosci 9: 257-272, 2007.

31. Filipski E, Subramanian P, Carrière J, Guettier C, Barbason H and Lévi F: Circadian disruption accelerates liver carcinogenesis in mice. Mutat Res 680: 95-105, 2009.

32. Logan RW, Zhang C, Murugan S, et al: Chronic shift-lag alters the circadian Clock of NK cells and promotes lung cancer growth in rats. J Immunol 188: 2583-2591, 2012.

33. Yang SL, Yu C, Jiang JX, Liu LP, Fang X and Wu C: Hepatitis $B$ virus $X$ protein disrupts the balance of the expression of circadian rhythm genes in hepatocellular carcinoma. Oncology letters 8: 2715-2720, 2014

34. Kelleher FC, Rao A and Maguire A: Circadian molecular Clocks and cancer. Cancer Lett 342: 9-18, 2013.

35. Haase VH: The VHL tumor suppressor: master regulator of HIF. Curr Pharm Des 15: 3895-3903, 2009.

36. Keith B, Johnson RS and Simon MC: HIF1 $\alpha$ and HIF2 $\alpha$ : sibling rivalry in hypoxic tumour growth and progression. Nat Rev Cancer 12: 9-22, 2012.

37. Loboda A, Jozkowicz A and Dulak J: HIF-1 versus HIF-2 - is one more important than the other? Vascul Pharmacol 56: 245-251, 2012.

38. Hsu CM, Lin PM, Lai CC, Lin HC, Lin SF and Yang MY: PER 1 and Clock are potential circulating biomarkers for head and neck squamous cell carcinoma. Head Neck 36: 1018-1026, 2013.

39. Yang SL, Liu LP, Jiang JX, Xiong ZF, He QJ and Wu C: The correlation of expression levels of HIF-1 $\alpha$ and HIF- $2 \alpha$ in hepatocellular carcinoma with capsular invasion, portal vein tumor thrombi and patients' clinical outcome. Jpn J Clin Oncol 44: 159-167, 2014. 